\title{
USE OF BASE METAL CASTING ALLOYS FOR IMPLANT FRAMEWORK: MARGINAL ACCURACY ANALYSIS
}

\author{
USO DE LIGAS METÁLICAS BÁSICAS EM PRÓTESES SOBRE IMPLANTES: \\ ANÁLISE DA ADAPTAÇÃO MARGINAL
}

\author{
Stefania Carvalho KANOํ, Gerson BONFANTE², Raquel HUSSNE ${ }^{3}$, Aline F. SIQUEIRA ${ }^{4}$
}

1- DDS, MS, PhD student, Department of Prosthodontics, Bauru Dental School, University of São Paulo, Bauru - SP, Brazil.

2- DDS, MS, PhD - Associate Professor, Department of Prosthodontics, Bauru Dental School, University of São Paulo, Bauru - SP, Brazil.

3- Resident, Hospital of Rehabilitation of Craniofacial Anomalies, University of São Paulo, Bauru - SP - Brazil.

4- DDS, MS, Student - Federal University of Santa Catarina - UFSC - SC - Brazil.

Corresponding address: Stefania Carvalho Kano - Al. Otávio Pinheiro Brizola 9-75 - Bauru SP Cep.: 17012-901

phone: 14 3235-8277 - Email: stekano@uol.com.br

Received: April 06, 2004 - Returned for modification: June 01, 2004

\begin{abstract}
$T$

The original protocol for implant prosthesis recommends the use of a gold framework for acrylic and ceramic prosthesis. However, due to its high cost, the use of alternative alloys is desired. This study compares the marginal accuracy of pre-made cylinders versus plastic cylinders cast with two different base metal casting alloys. Five samples each of (1) plastic cylinder cast in cobalt-chromium alloy, (2) plastic cylinder cast in nickel-chromium alloy, and (3) silver-palladium pre-made cylinder (control) were examined for marginal accuracy according to: (A) vertical gap; (B) horizontal gap and (C) horizontal gap depth at the abutment/cylinder interface. Data were submitted to statistical analysis (ANOVA and Student-Newman Keuls, $\mathrm{p}<0.05$ ). Mean values for vertical, horizontal and gap depth were $4.13 \mu \mathrm{m}, 14.5 \mu \mathrm{m}$ and $6.93 \mu \mathrm{m}$ for pre-made cylinder, $23.18 \mu \mathrm{m}, 33.2 \mu \mathrm{m}$ and $88 \mu \mathrm{m}$ for Ni-Cr cast cylinder and $25.6 \mu \mathrm{m}, 51.8 \mu \mathrm{m}$ and $114.54 \mu \mathrm{m}$ for Co-Cr cast cylinder. No statistically significant differences were found between cast groups ( 1 and 2 ), but significant better fit was obtained with pre-made metal cylinders when compared to cast cylinders with $\mathrm{Ni}-\mathrm{Cr}$ and $\mathrm{Co}-\mathrm{Cr}$ alloys, for all analyses.

Uniterms: Implant prosthesis; Alloys, misfit.
\end{abstract}

\section{RESUMO}

$O$ protocolo para prótese sobre implantes recomenda o uso de uma infra-estrutura em ouro para próteses metalo-plásticas e metalo-cerâmicas. No entanto, devido ao seu alto custo, o uso de ligas alternativas é desejado. Objetivo: Este estudo compara a adaptação marginal de cilindros protéticos pré-fabricados e cilindros protéticos plásticos fundidos com dois tipos de ligas metálicas básicas. Material e métodos: 05 amostras de (1) cilindros plásticos fundidos em liga de cobalto cromo; (2) cilindros plásticos fundidos em liga de níquel cromo e (3) cilindros pré-fabricados com cinta metálica em paládio, foram examinados na interface intermediário/cilindro protético na análise de desajuste marginal, considerando-se (A) desajuste vertical, (B) desajuste horizontal e (C) profundidade de fenda. Resultados: os valores médios para o desajuste vertical, horizontal e profundidade foram, respectivamente, $4,13 \mu \mathrm{m}, 14,5 \mu \mathrm{m}$ e $6,93 \mu \mathrm{m}$ para o cilindro pré-fabricado em paládio, 23,18 $\mu \mathrm{m}$, 33,2 $\mu \mathrm{m}$ e $88 \mu \mathrm{m}$ para os cilindros plásticos fundidos em Níquel cromo e 25,6 $\mu \mathrm{m}, 51,8 \mu \mathrm{m}$ e 114,54 $\mu \mathrm{m}$ para os cilindros fundidos em cobalto-cromo. Conclusão: não foram encontradas diferenças estatísticas entre os grupos fundidos (grupo 1 e 2 ), mas uma adaptação marginal significantemente superior foi observada com os cilindros pré-fabricados quando comparado aos cilindros plásticos fundidos com níquel-cromo e cobalto-cromo para todas as análises.

Unitermos: Prótese sobre implantes; Ligas, ajuste.

\section{INTRODUCTION}

The development of osseointegration allowed a longterm predictable solution for totally and partially edentulous patients. In spite of the high prosthetic success rates 7,17 , long-term studies have demonstrated a high prevalence of prosthodontic complications ${ }^{3,7,8,20}$ and the most common complication is screw loosening. Jemt, Linden, Lekholm ${ }^{7}$ 
showed a $49 \%$ rate of screw failure for maxilla and $20.8 \%$ for the mandible, accounting for $13 \%$ of prosthesis mobility.

The literature has emphasized the need of a passive fit restoration for long-term success of osseointegration ${ }^{15,18,20}$ and many techniques have been proposed to achieve a passive fit restoration ${ }^{19}$. In fact, each step of prosthesis fabrication influences the final $\mathrm{fit}^{14}$. To improve or even assure a better fit, the use of pre-made components has been highly recommended ${ }^{1}$. However, pre-made cylinders use high gold and silver-palladium alloys for framework casting, and their melting ranges are not compatible to alternative alloys ${ }^{12}$.The high cost of this type of framework has led to the development of plastic components allowing the use of alternative alloys, like base metal alloys.

The aim of this paper is to compare the marginal accuracy obtained by plastic components cast with two chromium type alloys and the marginal fit of pre-made metal cylinders.

\section{MATERIALAND METHODS}

Plastic cylinders and metal cylinders for standard abutments were used in this study according to the following groups:

Group 1 - Five plastic cylinders (Conexão Sistema de Próteses Ltda, São Paulo, Brazil) for standard abutment were cast with Cobalt-Chromium (Co-Cr) alloy (Rexilium ${ }^{\circledR}$ NBF, Jeneric Pentron ${ }^{\circledR}$ Incorporated, MT, USA).

Group 2 - Five plastic cylinders (Conexão Sistema de Próteses Ltda, São Paulo, Brazil) for standard abutment were cast with Nickel-Chromium (Ni-Cr) alloy (Verabond II, AalbaDent, Inc.,CA, USA).

Group 3-Five metal silver-palladium pre-made cylinders ( Conexão Sistema de Próteses Ltda, São Paulo, Brazil) for standard abutment were analyzed as received, and used as a positive control group.

The cast specimens of groups 1 and 2 were produced using the plastic cylinders that were invested in phosphatebonded investment (Talladium Micro-fine 1700, Talladium do Brasil Inc. - Comércio de Materiais de Prótese Odontológica, Curitiba, Paraná, Brasil) according to the manufacturer's instructions. Each component was cast individually. Alloys composition and melting range are listed in Table 1. Divesting was carefully performed and no further finishing and polishing procedure was performed.

One external hex implant (Conexão Master 10mm, Conexão Sistema de Próteses Ltda, São Paulo, Brazil) was embedded in an acrylic resin model (Duralay, Reliance Dental, Worth, IL, USA) and a Standard Abutment (Standard Abutment, Conexão Sistema de Próteses Ltda, São Paulo, Brazil) was tightened to $20 \mathrm{Ncm}$.

The abutment/cylinder interface for each specimen studied was analyzed at 8 different locations around the interface, according to the resin model design, using an optical microscope Mitutoyo TM 505 (Mitutoyo Corporation, Tokyo, Japan), with 150x magnification equipped with Digimatic Micrometer Heads 164-162 (Mitutoyo Corporation, Tokyo, Japan).

Three analyses were carried out for all groups: (A) vertical and (B) horizontal gap and (C) horizontal depth gap (Figure 1)

Figure 2 illustrates the dimension of the expected horizontal surface of contact at the abutment/cylinder interface of the conventional abutment and prosthetic cylinders used in this study.

Mean values for each analysis were obtained for each specimen and for each group and then were submitted to one-way analysis of variance $(\mathrm{p}<0.05)$ and to the StudentNewman-Keuls test.

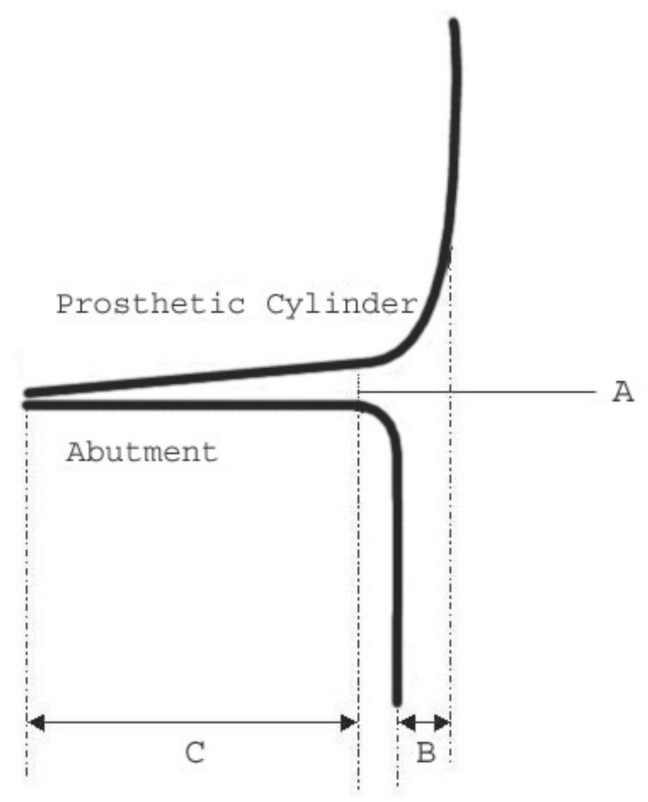

FIGURE 1- Marginal Fit Analysis: A - vertical gap; B horizontal gap; C-horizontal depth gap

TABLE 1- Casting Alloy Composition (wt\%) and casting temperature

\begin{tabular}{lcccccccccc}
\hline & Ni & Cr & Co & Mo & Si & Nb & Al & W & Ga & Melting Range ${ }^{\circ} \mathbf{C}$ \\
\hline Verabond II** & 75.55 & 11.50 & 3.50 & 3.50 & 4.25 & 2.25 & & & $1,200-1,315$ \\
Rexilium ${ }^{* N B F^{*}}$ & 25 & 52 & & & & & 14 & 8 & $1,232-1,315$ \\
\hline
\end{tabular}

*Rexilium ${ }^{\circledR}$ NBF, Jeneric Pentron ${ }^{\circledR}$ Incorporated, MT, USA

**Verabond II, Aalba-Dent Inc., CA, USA 


\section{RESULTS}

Mean values and standard deviations for vertical and horizontal gap, as well as the horizontal depth of gap, are shown in Table 2.

Significant differences were found for all analyses for $\mathrm{p}<0.05$. (Table 3 to 5 ). Student-Newman-Keuls test revealed that the control group presented significantly better fit than both tested groups for all analyses. Significant differences $(\mathrm{p}<0.05)$ were also found when group 1 was compared to group 2 for the horizontal gap analysis (Table 2).

\section{DISCUSSION}

The use of alternative alloys in conventional prosthodontics is widely accepted due to the good properties of these alloys, but mainly for their low cost when compared to gold alloys. More than $80 \%$ of dentists in the United States use metal base alloys containing nickel, chromium and beryllium ${ }^{16}$.

For implant prosthesis, framework manufacture consists of casting-on to prefabricated gold alloy cylinders. In this manner, casting alloys must be chosen on the basis of the thermal properties relative to the cylinders and the temperature of cast molten alloy should not closely approach the solidus temperature of the cylinder. Usually, metal premade cylinders are made of gold or silver-palladium alloy with melting range around $1280^{\circ} \mathrm{C}$ to $1350^{\circ} \mathrm{C}$ (melting range for standard gold cylinders, Nobelbiocare) and therefore chosen casting alloys should not have a liquidus temperature much above $1000^{\circ} \mathrm{C} .{ }^{21}$ Since Nickel-Chromium and CobaltChromium alloys have a melting range around $1200^{\circ} \mathrm{C}$ and $1315^{\circ} \mathrm{C}$ (Table 1 ), they should not be used with pre-made gold cylinders. Plastic cylinders are the only available option if this type of alloy is to be used.
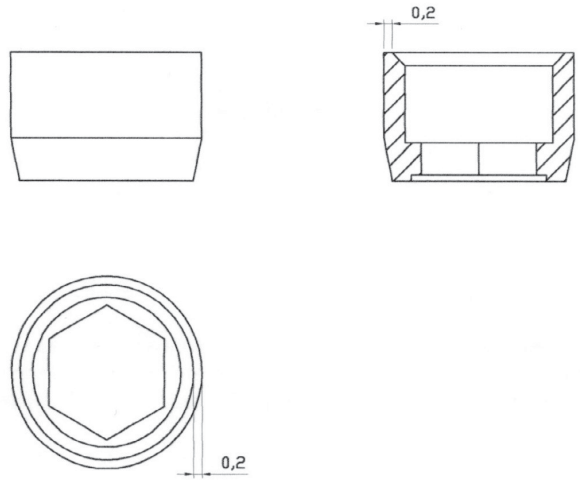

$2 a$
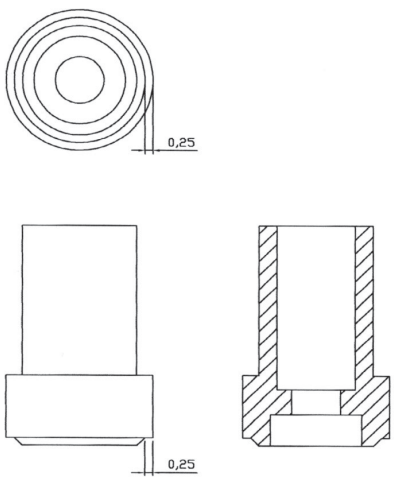

2c

TABLE 2- Mean values $(\mu \mathrm{m})$ for each group. Bars represent values that do not differ significantly (Student-Newman-Keuls $-p<0.05)$

\begin{tabular}{lcccccc}
\hline Group & \multicolumn{2}{c}{ Vertical Misfit } & \multicolumn{2}{c}{ Horizontal Misfit } & \multicolumn{2}{c}{ Gap Depth } \\
& Mean & SD & Mean & SD & Mean & SD \\
\hline 1-Co-Cr & 25.06 & 7.75 & 51.8 & 28.22 & 114.54 & 53.79 \\
2-Ni-Cr & 23.18 & 6.96 & 33.2 & 18.39 & 88.0 & 32.19 \\
3-pre-made cylinder & 4.13 & 4.29 & 14.5 & 5.97 & 6.93 & 2.74 \\
\hline
\end{tabular}

TABLE 3- Results of 1-way analysis of variance for Vertical Misfit

\begin{tabular}{llcccc}
\hline Source of Variance & $\boldsymbol{d} \boldsymbol{f}$ & Sum of squares & Mean square & F value & $\boldsymbol{P}$ value \\
\hline Between Treatments & 2 & 1341.1 & 670.6 & 15.8 & 0.0004 \\
Residual & 12 & 507.8 & 42.3 & - & - \\
Total & 14 & 1848.9 & - & - & - \\
\hline
\end{tabular}


When plastic cylinder components are used, the conventional lost wax technique is used and the contact surface of the cylinder as well as the internal cylinder surface is influenced by a variety of processing and handling conditions of the fabrication process, as well as the casting accuracy of the alloy ${ }^{11}$.

In fact, for all analyses carried out in this study, marginal discrepancies for cast components obtained from plastic cylinders were statistically higher than for pre-made cylinders. Figure 3 shows the aspect of a pre-made cylinder and Figures 4 and 5 show the aspect of a plastic cylinder after casting procedure. When comparing Figures 4 and 5 to Figure 3, the superiority of pre-made cylinders is evident. Figures 6 and 7 show the abutment/cylinder interface when a cast cylinder and a pre-made cylinder is used.

A clinical trial carried out by Jemt, Book ${ }^{6}$ could not found a statistically significant correlation between marginal bone level and prosthesis misfit. But, when considering the mechanical aspect of the implant prosthesis, poor fitting prosthesis with $6 \mu \mathrm{m}$ to $10 \mu \mathrm{m}$ vertical misfit may lead to screw loosening $^{5,8}$. In this study, vertical gap of cast cylinders of $23.18 \mu \mathrm{m}$ (Ni-Cr) and 25.06 (Co-Cr) were found, 5 to 6 times greater than for pre-made cylinders $(4.13 \mu \mathrm{m})$.

In a previous study, Kano, et al. ${ }^{9}$ compared the vertical misfit obtained after casting procedures when plastic cylinders and gold cylinders were used. Even though higher values were obtained for all groups when compared to present study, both studies clearly demonstrate that casting procedures do influence the final fit of prosthetic components when plastic cylinders are used, no matter what type of alloy is used. The initial fit of plastic cylinders can be responsible for the results obtained since even pre-made metal cylinders present a marginal misfit. Marginal discrepancies of the as-received metal cylinders can vary from $0.5 \mu \mathrm{m}$ to $5.04 \mu \mathrm{m}$, depending on the implant system used and as high as $46.9 \mu \mathrm{m}$ when components from different manufacturers are combined ${ }^{10}$.

The inability to produce a surface free of irregularities and the impossibility to finish and polish the final surface with reliability may be the reasons for discrepancies observed.

When analyzing horizontal misfit frameworks, Patterson, Johns ${ }^{13}$ have stated that when implant parts are not correctly aligned, internal connecting screws are more susceptible to fracture or loosening. According to White ${ }^{21}$, this can happen because abutment replicas have a lateral fitting error. In this study, the mean horizontal misfit of pre-made cylinders was $14.5 \mu \mathrm{m}$ before submitted to any laboratory procedure. This means that no matter how careful is the framework fabrication process, the final prosthesis will be delivered with some degree of horizontal misfit. And when plastic cylinders are cast, significant higher horizontal misfit is to be expected, as seen in this study where horizontal misfit of $33.2 \mu \mathrm{m}$ for $\mathrm{Ni}-\mathrm{Cr}$ alloy and $51.8 \mu \mathrm{m}$ for Co-Cr was observed.

When implant prosthesis is screwed in place, the torque applied to the screw creates a preload which keeps the components together. The higher the preload, the higher will be the ability of the screw to withstand the external loads without loosening. Changes in the surface of the cylinder can influence preload because $50 \%$ of the torque is influenced by friction of this area and part of the preload can be lost when the screw is used to bring components together ${ }^{4}$.

During microscopic analysis of specimens, vertical and horizontal marginal discrepancies of cast components were evident, but a careful look at the abutment/cylinder interface of cast components demonstrated that contact surface between both components was very compromised by the depth of the gap. Figure 2 shows that the area of contact at the abutment/prosthetic component interface is a $0.20 \mathrm{~mm}$ $(200 \mu \mathrm{m})$ flat surface for the standard abutment and a $0.25 \mathrm{~mm}$ $(250 \mu \mathrm{m})$ surface for the prosthetic cylinders. When plastic components were cast in Co-Cr alloy, a mean depth gap of $134.5 \mu \mathrm{m}$ was created, for example, only one third of the abutment contact surface was really in contact with cast cylinder (Figure 8A and 8B). This lack of contact between

TABLE 4- Results of 1-way analysis of variance for Horizontal Misfit

\begin{tabular}{llcccc}
\hline Source of Variance & $\boldsymbol{d f}$ & Sum of squares & Mean square & Fvalue & $\boldsymbol{P}$ value \\
\hline Between Treatments & 2 & 3479.8 & 1739.9 & 4.46 & 0.0356 \\
Residual & 12 & 4680.1 & 390.0 & - & - \\
Total & 14 & 8159.9 & - & - & - \\
\hline
\end{tabular}

TABLE 5- Results of 1-way analysis of variance for Gap Depth

\begin{tabular}{llcccc}
\hline Source of Variance & $\boldsymbol{d} \boldsymbol{f}$ & Sum of squares & Mean square & F value & $\boldsymbol{P}$ value \\
\hline Between Treatments & 2 & 31430.2 & 15715.1 & 12.0 & 0.0014 \\
Residual & 12 & 15747.1 & 1312.3 & - & - \\
Total & 14 & 47177.3 & - & - & - \\
\hline
\end{tabular}




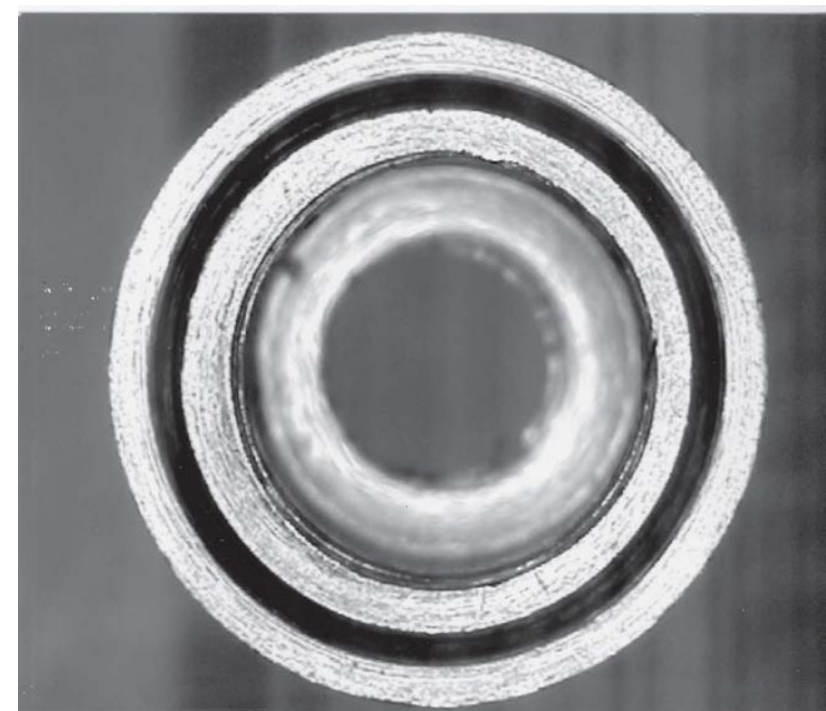

FIGURE 3- Pre-made metal cylinder

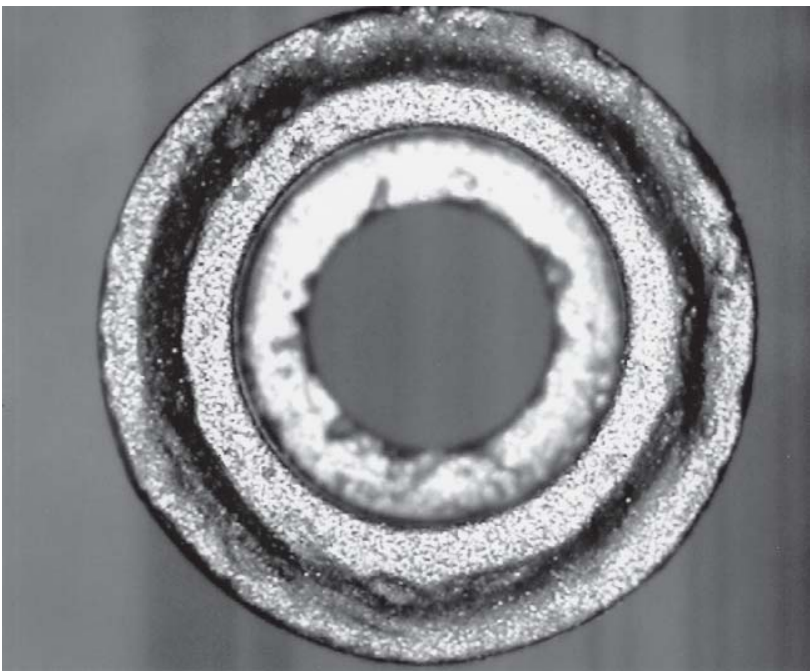

FIGURE 4- Plastic cylinder cast with $\mathrm{Ni}-\mathrm{Cr}$ alloy

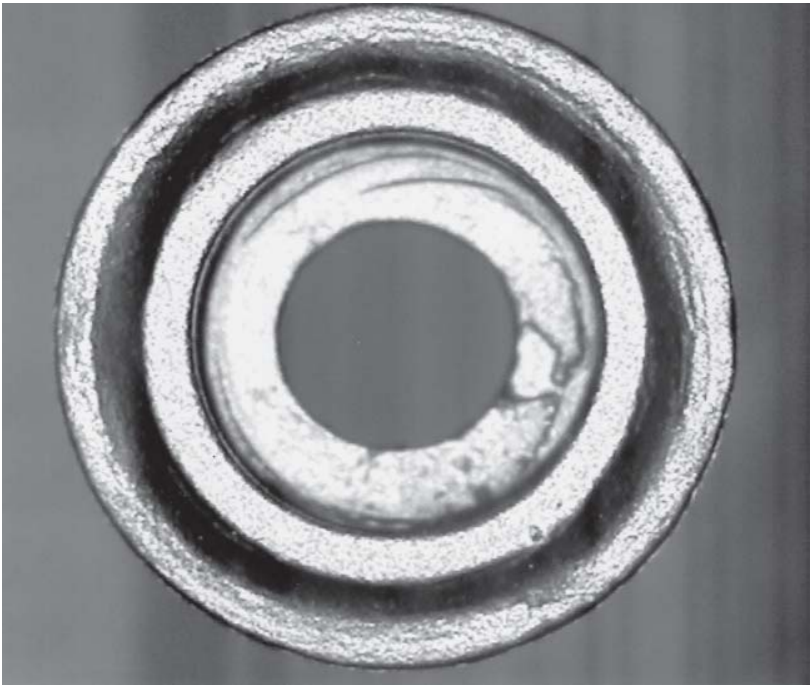

FIGURE 5- plastic cylinder cast with Co-Cr alloy

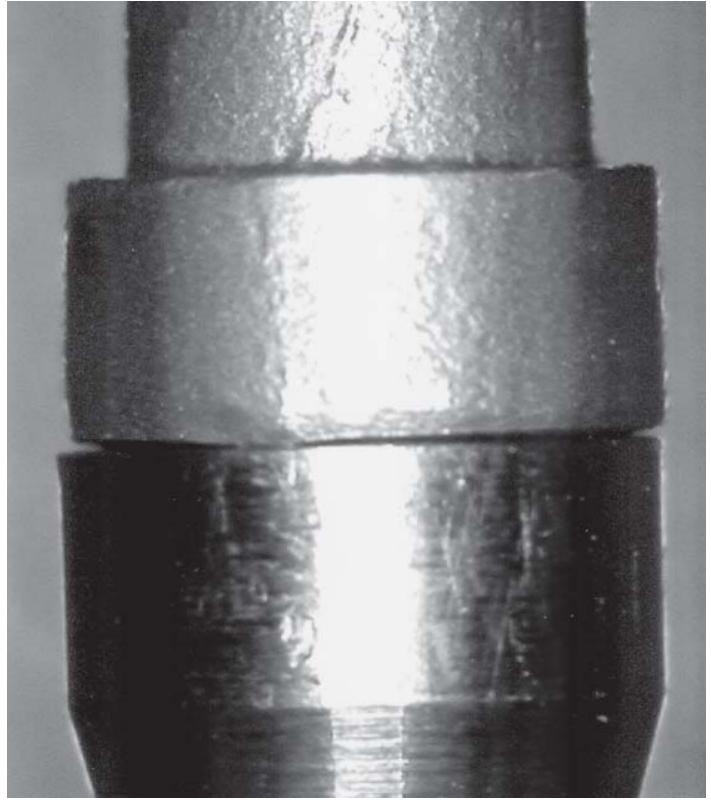

FIGURE 6- Abutment/cast cylinder interface: vertical and horizontal gap and horizontal depth gap

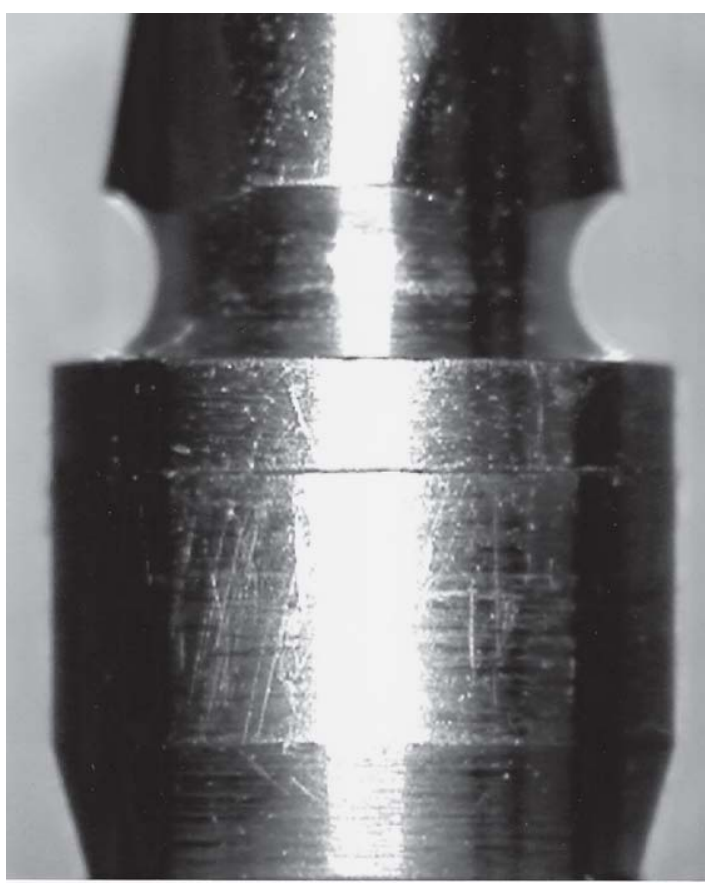

FIGURE 7- Marginal fit of pre-made metal cylinder at the abutment/cylinder interface

both components may lead to tilting and rocking of the final restoration, which may cause the screw loosening and fracture ${ }^{4,2}$.

Although the present literature lacks in providing conclusive results on the role of marginal fit of implant prosthesis in the screw loosening phenomena, and the great variables encountered in the use of plastic components for the fabrication of implant superstructure, the use of plastic components should be viewed with caution when precision and predictability is desired. Longitudinal clinical studies 


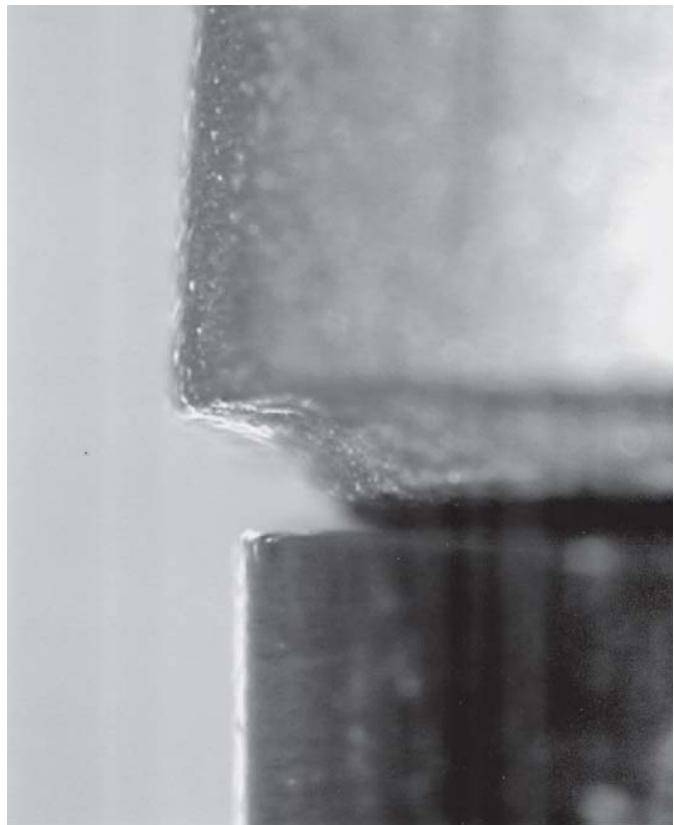

a

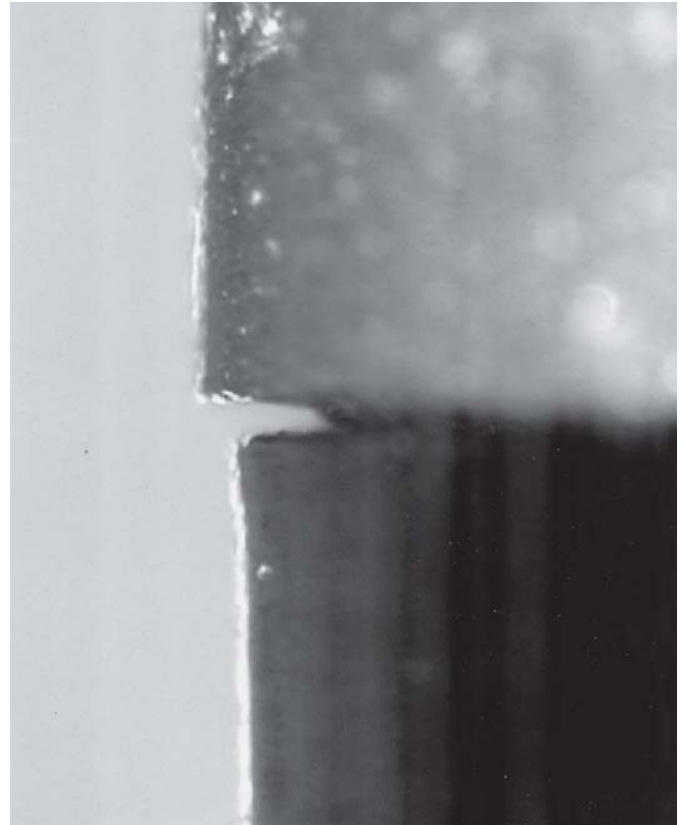

b

FIGURE 8- Horizontal Depth Gap at the abutment/cylinder interface of a cast cylinder: a) without screwing, note how small is the contact surface; b) components are screwed together, note that no contact exists at the interface

could be useful in providing valuable information on this issue.

\section{CONCLUSIONS}

Under the conditions of this study, the following conclusions can be made:

1. The mean marginal discrepancies for plastic cylinders cast with $\mathrm{Co}-\mathrm{Cr}$ and $\mathrm{Ni}-\mathrm{Cr}$ alloy were statistically different when compared to the pre-made metal cylinder, for vertical, horizontal and depth gap analysis, except for the horizontal misfit of the plastic cylinder cast with $\mathrm{Ni}-\mathrm{Cr}$ and pre-made cylinder.

2. The mean marginal discrepancies of plastic cylinders cast with $\mathrm{Co}-\mathrm{Cr}$ and $\mathrm{Ni}-\mathrm{Cr}$ were not statistically different when compared to each other.

\section{REFERENCES}

1- Binon PP et al. Implant component compatibility. In: Laney WR, Tolman DE, editors. Tissue integration in oral, orthopedic, and maxillofacial reconstruction. Chicago: Quintessence; 1990. p.21826.

2- Binon PP. Implants and Components: entering the new millennium. Int J Oral Maxillofac Implants 2000;15:76-94.

3- Carlson B, Carlsson GE. Prosthodontic complications in osseointegrated dental implant treatment. Int J Oral Maxillofac Implants 1994;9:90-4.

4- Carr AB, Brunski JB, Hurley E. Effects of fabrication, finishing, and polishing procedures on preload in prostheses using conventional 'gold' and plastic cylinders. Int J Oral Maxillofac Implants 1996; 11: 589-98.

5- Isa ZM, Hobkirk JA. The effects of superstructure fit and loading on individual implant units: Part I. The effects of tightening the gold screws and placement of a superstructure with varying degrees of fit. Eur J Prosthodont Restor Dent 1995; 3: 247-53

6- Jemt T, Book K. Prosthesis misfit and marginal bone loss in edentulous implant patients. Int J Oral Maxillofac Implants 1996; 11: $620-5$.

7- Jemt T, Linden B, Lekholm U. Failures and complications in 127 consecutively placed fixed partial prostheses supported by Branemark implants: from prosthetic treatment to first annual checkup. Int J Oral Maxillofac Implants 1992; 7: 40-44.

8- Kallus T, Bessing C. Loose gold screws frequently occur in fullarch fixed prostheses supported by osseointegrated implants after 5 years. Int J Oral Maxillofac Implants 1994; 9:169-78.

9- Kano SC, Valle AL, Pegoraro LF, Campos Jr A. Disadjustment of prosthetic components using different alloys [abstract n. 206] J Dent Res 1995;74:806.

10- Kano SC. Avaliação da adaptação da interface intermediário/ cilindro de ouro e da compatibilidade de diferentes sistemas de implantes odontológicos: análise intra e entre sistemas. Bauru; 1998 [Thesis M.S. Bauru School of Dentistry University of São Paulo].

11- Lewis SG, Llamas D, Avera S.The UCLA abutment: a four-year review. J Prosthet Dent 1992; 67:509-15.

12- O’Brien WJ. Base metal casting alloys. In: O’Brien WJ, editor. Dental material and their selection. Carol Stream; Quintessence; 1997. p.259-68.

13- Patterson EA, Johns RB. Theoretical analysis of the fatigue life of fixture screws in osseointegrated dental implants. Int J Oral 
Maxillofac Implants 1992;7:26-33.

14- Sahin S, Cehreli MC. The significance of passive framework fit in implant prosthodontics: current status. Implant Dent 2001; 10:8592.

15- Skalak R. Biomechanical considerations in osseointegrated prostheses. J Prosthet Dent 1983; 49: 843-8.

16- Sorensen JA, Kang SK, Torres TJ et al: In-Ceram fixed partial dentures: three-year clinical trial results. J Calif Dent Assoc, 1998;26:207-14.

17- Taylor TD, Agar JR, Vogiatzi T. Implant prosthodontics: current perspective and future directions. Int J Oral Maxillofac Implants 2000; 15:66-75

18- Waskewicz GA, Ostrowski JS, Parks VJ: Photoelastic analysis of stress distribution transmitted from a fixed prosthesis attached to osseointegrated implants. Int J Oral Maxillofac Implants 1994; 9:405-11.

19- Wee AG, Aquilino SA, Schneider RL. Strategies to achieve fit in implant prosthodontics: a review of the literature. Int J Prosthodont 1999;12:167-78.

20- Weinberg LA. The biomechanics of force distribution in implantsupported prostheses. Int J Oral Maxillofac Implants 1993; 8:19-31.

21- White GE. Osseointegrated Dental Technology. Chicago: Quintessence; 1993 